\title{
千葉縣市川市鬼高泥炭層發掘の自然遺物
}

直良信 夫

\section{1. 踷害}

杉原莊介氏の發掘てか」るものであつて、自然遺物としては動物及植物を出土した。 今杉原氏の依啒てなる之等の標品を考稝してみるのにその種類は下記の如きものであ る。(但し貝類を除く)

動 物

䜤椎動物

㷛 颣

イ サ Parapristipoma cf. trilineatum (Thunberg)

$\checkmark$ ダ 1 Pagrosomus major (Tem. et Sch.)

マフグの一種？ Spheroides sp. ?

コ チ Platycephalus indicus (Linnaeus)

七 ラ. $\times \quad$ Paralichthys olivaceus (Tem. and Sch.)

鳥 類

タンテウ Grus (Grus) cf. japonensis (Müller)

哺乳類

シツポンジカＣervus nippon nippon Tem.

エジジカ C. yesoensis Heude

植 物

雙子葉植物

七泣

Trapa natans L. var. bispinosa Makino

モ

Prunus Persica Sieb. et Zucc. var. vulgalis Maxim.

クリ

Castanea vulgaris Lam. var. japonica A. DC. 
ク ミ

Juglans Sieboldiana Maxim.

2. 種の略 記載 (計測數字の單位は凡て m.m.)

動 物

㷛 類

イサキ Parapristipoma cf. trilineatum (Thunberg)

有側上顎筲、小さい残恬である。

マダイ Pagrosomus major (Tem. et Sch.)

頭简 非常に大形のものである。前頭骨はその前邊を少缺してるるが、頭骨は唇く、

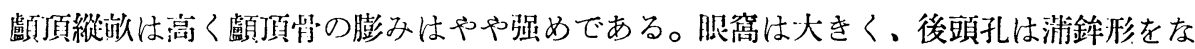
して中夙大、後頭髁の突出は强い。

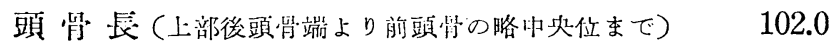

顱烦胃幅 20.0

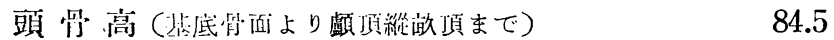

前頭骨幅（腿窝後渗） 52.5

後頭 孔. 上下徑 $\times$ 左右徑 $10.0 \times 12.0$

後頭 孔. 左右徑. 22.0

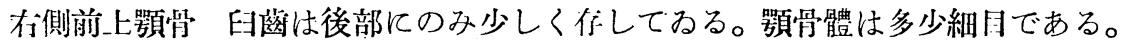

上顎骨辰 (多少後端缼)

25.5

上顎骨體高 $\quad 9.5$

上颢骨體厚

マフグの一種？ Spheroides sp.?

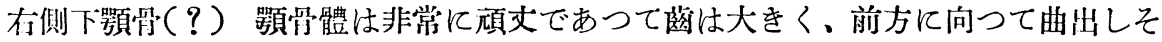

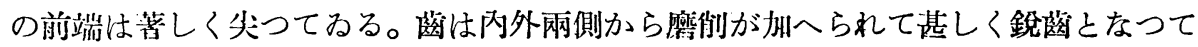
みる。

顎 骨 長

55.5

䍃長

45.5

落高

27.5

コチ Platycephalus indicus (L.)

杉原氏の語る所によれば本種の頭骨が略完全に近く復原される程度にあつたとい 
S.0

ヒラメ Paralichthys olivaceus (Tem. and Sch.)

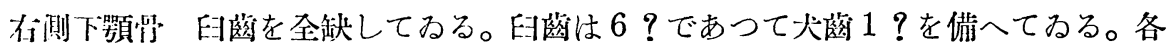

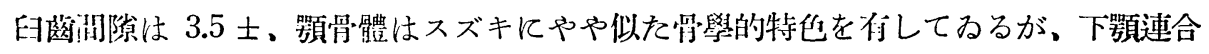
部前端の上綾恃著しく棘状飞塋出する。

顎 骨”長 (後端多少䟜)

57.0

一顎骨體高

24.0

下顎骨體厚

鳥 類

タンテウ Grus (Grus) cf. japonensis (Müller)

右側上膊骨破片 大形のものであつて上膊頭は著しく圓頭をなして大きく、內結算

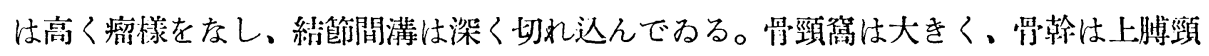
と外結節間下から中央にかけて縱に隆起する度が强い。

上膊骨上端上下徑

$45.5+$

上膊 肙 队外潩

18.5

需翰（略中央位と推定せられる部分に於て）內外徑 $\times$ 上下徑 $13.5 \times 15.0$

この上膊骨はマナッ゙ルのののものと可成近似した骨相を有してるるものであるが、 體の中央を縱走する隆起帶の位㯰と骨巠窝內側緣の隆起飞少異があり、之等の諸點は 寧ろタンテウに於て侍する骨相であるが、然し骨體縱走の高まりはタンテウのものと も全く同相を呈してるるとはいひ得ないのであるが、大きさ及び全體の骨相の颣似點 よりして今假りに之をタンテウに對比して後考に俟ちたいと思ふ。

哺 乳類

ヘツポン鹿 Cervus nippon nippon Tem.

前頭骨殘片一1. 左側下顎骨殘片一1. 左側角翰部破片-2.

前頭骨师左存兩角坐骨を借へた小破㸝であつて、此の角坐骨を中心としてその前

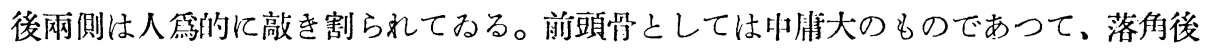

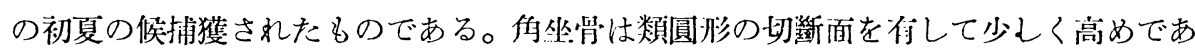
つて、龙右への閒展は强日である。庄存网㑇坐間の前位に於て正中線は可成槀まつて カる。 


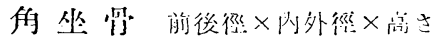

$27.0 \times 28.5 \times 32.0 \pm$

龙右网网的坐需頂部內盄

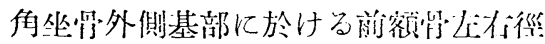

95.0

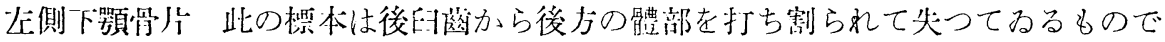

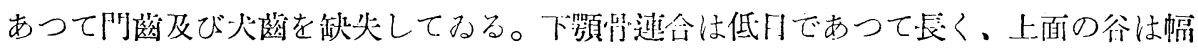

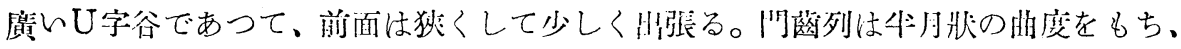

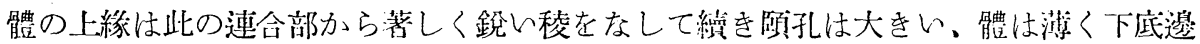

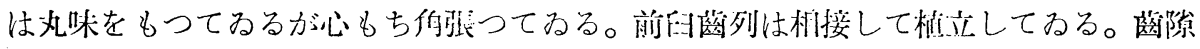
は辰い。

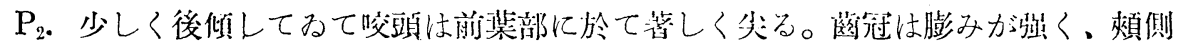

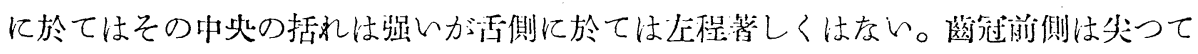

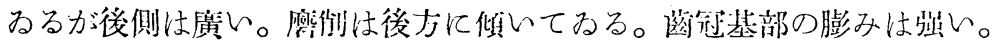

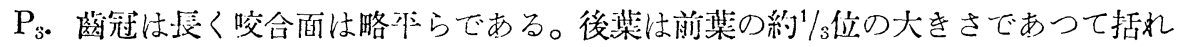

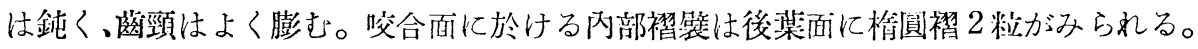

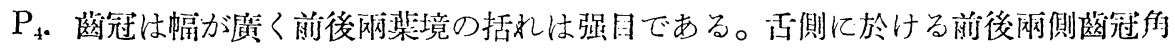
は尖つてみて、各葉煩側縁は可成丸味をもつて展出してるる。咬合面に於ける內部褶 壁は兩葉境と前葉部に於てみられる。珐響翼厚は厚い。

下颚遇合長×巾×简さ

落隐長

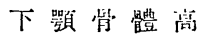

蓠隐巾央

$\mathrm{P}_{2}$

$P_{3}$

$P_{4}$

$\mathrm{i}_{1}$ - $\mathrm{i}_{3}$ 苳槽長

$\mathrm{P}_{2}-\mathrm{P}_{4}$ 荻列長

落起長
15.0

26.0

27.5

28.5
$34.0 \times 13.0 \times 18.0$

62.0

下 颚體 19

8.5

9.5

11.0

12.5

12.0

35.0

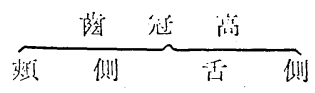

is $("$ " ) 3.5

$\mathrm{i}_{3}$ (" I) 3.0

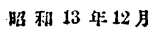

8.2

3.5

4.5

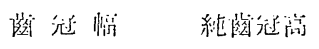

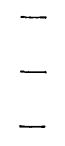




$\begin{array}{lrrrrr}\mathrm{C} \quad \text { ( " }) & 4.0 & 5.0 & - & - & - \\ \mathrm{P}_{2} & 9.5 & 6.5 & 7.3 & 8.5 & 8.0 \\ \mathrm{P}_{3} & 1.2 .5 & 7.5 & 5.5 & 7.0 & 7.5 \\ \mathrm{P}_{4} & 13.5 & 9.5 & 6.0 & 7.0 & 8.0\end{array}$

解第 1 標本 第 2 忮下部に於て伆翰を輸切にして截除したものであつて、角は 中形である。第 2 枝下の角翰は卵形の切斷面形をもち、第 2 枝は角翰飞對して70度を 保ち、枝長は短かく、その基部は偏本であつて枝の上邊は少しく尖つてるる。第 2 枝 .上邊の角翰は 90.0 の位置に於て切截せられてるて解冠の状況は推知し得られないが。 角は前後に向つて著しく偏平になつてみる。解翰の外側に於ける絬䈱の發達は鈍いが

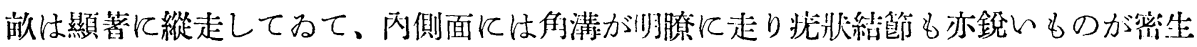
してみる。

第 2 標本 乙れは触基部の殘片であつて第 1 枝通上に於て触翰は人工的に切截せ

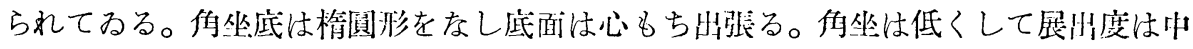

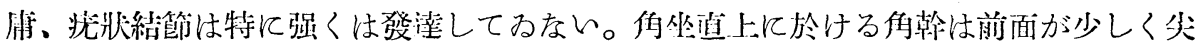
り氣味であるから全體として卵形の切䋨面をなしてるる事が知られる。的股はやや廣 く內外面側面とも少しく䠰む。鿇坐底から第 1 枝上背までの高さは低目であつて第 1 枝は角幹に對して約70度に分出し、第 1 枝は短かくして納く、可成偏平である。符 1 枝上邊に於ける角翰の斷面は胡桃果脶をなしてるる。

籍 1 㮐本 籍 2 㮐本

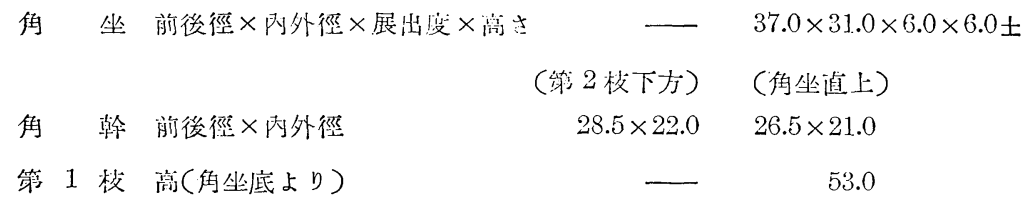

校長

(籍 2 校) (筙 1 校)

$56.0 \pm \quad 58.0 \pm$

校角装部 内外徑 $\times$ 上下徑 $\quad 3.5 .0 \times 26.0 \pm 1.2 .5 \times 20.0$

特徵及び考察 特別に之之いつて著しい特巴はもつてるないが、角にあつては、全 體が著しく細形であつて、第 1 枝が短小である點が目に立つ。此の手の媘角は一體に

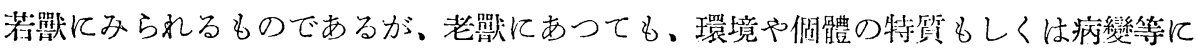
よつて鹿角の生長度に異變を來をしたものにもみられる。 


\section{エゾ磨 Cervus yesoensis Heude}

\section{左側下顎零片一3.}

第 1 標本 下顎骨體は $M_{3}$ 後葉位に於てその後部を破損してるる。下顎骨體は一體 に低目であつて且その上縁はややノルマルではない。下頙連合部は低くして長く、そ の正中縫合部面はニツポンジカ程複雜銳尖ではない、上面の谷は少しく淺く前面は著

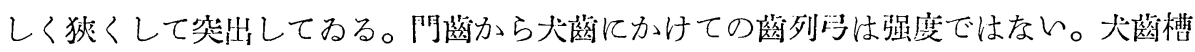

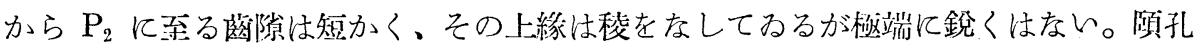
は大きい、下顎體の外側はやや膨みが强く內側面は遖截に近く、下底邊は厚くして丸

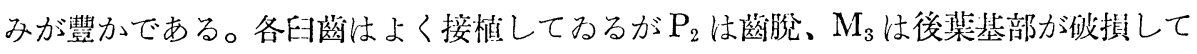
みる。

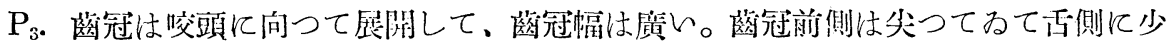

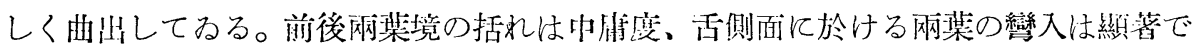
ある。咬頭は著しく尖つてるる。

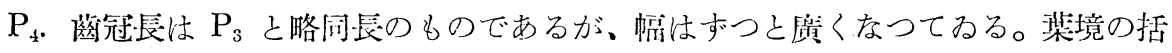

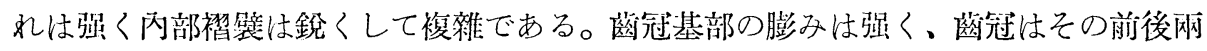
側の中央が可成しやくれてるる。

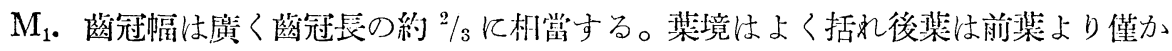

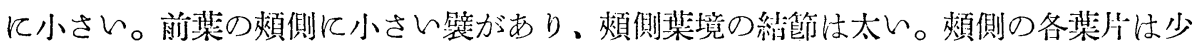

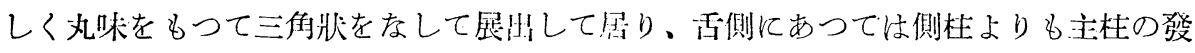

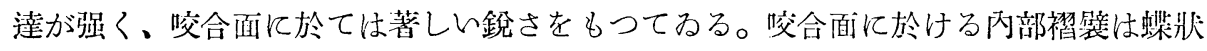
を呈してみる。珐瑯質は薄い。

$\mathrm{M}_{2}$. 甚しく大形であつて、蒛冠前側は著しく舌側に曲出し、後側に於ては煩側集後 側が䓕しく尖つて突出する。煩側各葉斤は大をい銃三们をなし、葉境の結節は錐狀を なして太く、前葉煩側壁に於ける壁は小さい。咬頭はよく尖り舌側に於ては主杜より 名各側柱が柱狀發達をなしてるる。

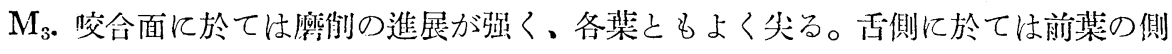

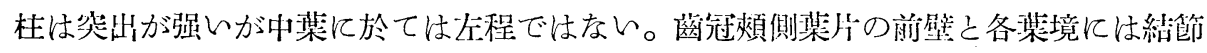
がみられる。後葉は掯鉾栐をなしてるる。

第 2 標本 この下顎骨は $M_{1}, M_{2}$ を植立したものであつて $M_{3}$ はまだ槽中にある。 


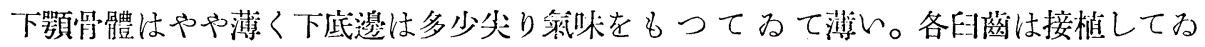
て、その性䟮忙第 1 標本と同樣のものである。

籍3 標本 $M_{1}, M_{2}$ を植立してるて $M_{3}$ は脘蒛、 $P_{4}$ は漸く萌出しつ」あるもので あつて、體の下底は破損してるる。 $M_{1}, M_{2}$ 将第 1 標本のものと同栐であつて特に記 すべき特やをもをない。

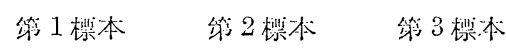

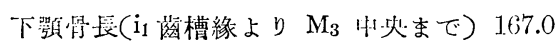

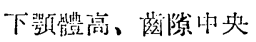

16.0

$\mathrm{P}_{2}$ 直下

$\mathrm{P}_{3} \quad$ "

$\mathrm{P}_{4} \quad$ "

$\mathrm{M}_{1}$ /

$\mathrm{M}_{2}$ "

$\mathrm{M}_{3} \quad$ "I

下颚體厚、落柗中央

\section{$\mathrm{P}_{2}$ 了直下}

$\begin{array}{ll}\mathrm{P}_{3} & \text { " } \\ \mathrm{P}_{4} & \text { " } \\ \mathrm{M}_{1} & \text { " } \\ \mathrm{M}_{2} & \text { " } \\ \mathrm{M}_{3}\end{array}$

菌隙長

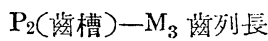

$\mathrm{P}_{2}$ (菌槽) $-\mathrm{P}_{4}$ 菌列長

$\mathrm{M}_{1}-\mathrm{M}_{3} \quad$ "

$\mathrm{M}_{1} \longrightarrow \mathrm{M}_{2} \quad$ "

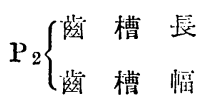

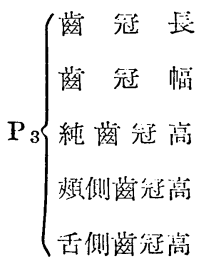

24.0

23.0

25.0

31.0

34.0

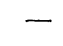

8.0

10.0

1.2 .5

14.5

15.5

18.0

18.0

52.5

103.5

40.0

65.5

39.0

9.5

5.5

16.0

9.0

13.5

13.5

12.5

(26)
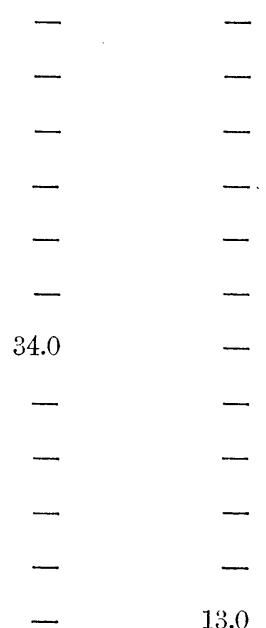

$15.5 \quad 15.0$

$17.0 \quad 17.3$
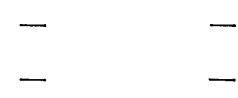

39.5

38.0

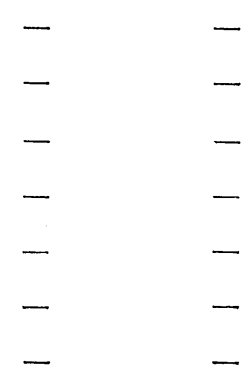

人精舁雜誌 53.12 
直长一千菜懸市川市鬼高泥岸層發插の自然遺物

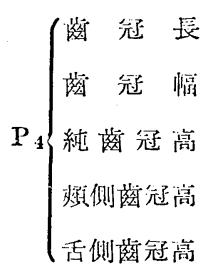

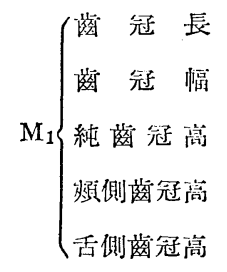

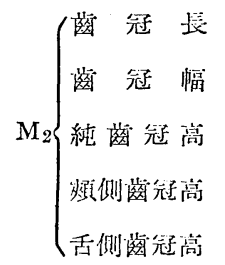

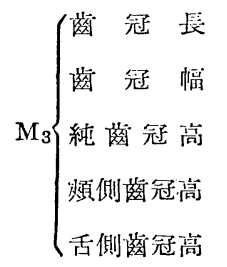

15.0

9.5

15.5

15.5

14.5

17.5

11.5

12.0

12.0

13.0

22.0

12.5

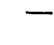

13.5

19.0

26.5

13.0

23.0

14.5

17.0
15.5

$9.0+$

$-$

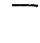

$-$

18.5

17.0

11.0

10.5

22.5

23.0

23.5

21.0

12.0

$11.5+$

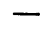

13.5

15.5

11.5

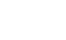

考察 此等の標本は、現生のものと殆んど大羙のないものである。

植 物

ヒシ Trapa natans L. var. bispinosa Makino

極めて微々たる殘片であるが、棘のみ僅か洒められる。

モモ Prunus Persica Sieb. et Zucc. var. vulgalis Max.

堅果は比較的大きん。

\begin{tabular}{|c|c|c|c|}
\hline & 㛑果 長 & 些 果 愘 & 紫果 牌 \\
\hline 栐本第 1 號 & 27.0 & 21.0 & 16.5 \\
\hline 同 第 2 號 & 27.5 & 21.5 & 16.5 \\
\hline
\end{tabular}

クリ Castanea vulgaris Lam. var. japonica A. DC.

果皮のみ壯土する。大きさは中庸のものである。

$ク ル ミ$ Juglans Sieboldiana Maxim. 
大きさは中簮、果頂はよく矢り、全體の膨みは强い。果溝は左程顯著ではない。

\begin{tabular}{|c|c|c|c|}
\hline & 卧果長 & 㹂果幅 & 堅 果厚(但し片側) \\
\hline 榄本第 1 號 & 35.0 & 24.0 & 10.0 \\
\hline 鬥 籍 2 號 & 33.0 & 23.0 & 11.0 (完企相に於て 21.0) \\
\hline
\end{tabular}

\section{3. 結尾}

以上によつてみると、鬼高泥炭層からは動物として魚鳥㗊の3 類、植物としては雙 子葉植物を出土した事が知られる。元來此の地點は、菱の繁生してみるやうな沼澤地 であつた事が考へられるのであるが、もとより、同出の魚貝類よりしてての沼は海岸 に接した程類のものであつた事は肋かであらう。この沼澤地には盧のやうなものも繁 茂してるた事と察せられるのであるが、それを園繞する池邊には濶葉樹が生繁り、そ の一部を開拓して、モモの如きものが栽培せられてみた。此のモモは、野生種と栽培 種(現在種)との中間樣のものであるが、束京师板橋區前野谷史前泥炭曆發掘品に比す ると、やや高級品であつた事が知られる。かくて、此の地の人及は、一方に於て㡲狩 りを行ひ、ある時は海に漁して魚介をあつめ、丈あるときは池沼に憩ふ小鳥類を捕獲 したりして生活してみたのである。從つてその生活樣式は、後期漱石器時代瓦衆の域 を左程著しく、出離れたものではなかつた。之は一面に於て、此の地一圓がまだ山㜪 海幸に䇺富であつて、自らを勞して營む農粪の倞在を必要としなかつた事に原因があ るのかも知れないが、他面に於て、文化の優劣も亦あづかつてカのあつた事だらら。 之を農罪の高度に發達してるた前野谷近傍の占代文化に比すると、全體としてその間 に、大をな開きの存するものである事を知る事が出來やう。古生物學的見地々於ては。 新石器時代にさへ、その例を多く見なかつた。大形のマダイの存在がまづ注目せられ、 同時に陸獸として、此の時代まで、マジジカが關東地方に分乍してみた事が、興味深 くながめられる。

\section{文獻}

動 物

Pisces

1934. B. SснтуцKo, A Neogene founa of Fresh-water fishes from Western Siberia, Transactions of the United Geological and prospecting Service of USSR. Fas. 359.

1936. A. Taranetz, On the Fish-bones found in the Dwelling places of the Ihlow Tribe, Bulletin of the Far Eastern branch of the Academy of Sciences of the USSR. No. 18. 
Aves

1932. H. Hownrd, Eagles and Eagle-like vultures of the Pleistocene of Rancho la brea, Carnegie Institution of Washington. Pub. No. 429.

Mammalia (Cervidae)

1885-1906. M. HEUDE, Histoire naturelle de L'empire Chinois.

1898. R. LydekKer, The Deer of all lands.

1929. H. MAtsumoto, Report of the mammalian remains obtained from the sites at Aoshima and Hibiku, Province of Rikuzen. Sci. Rep. Tohoku Imp. Univ., Sendai, Japan. Ser. 2, Vol. XIII, No. 3.

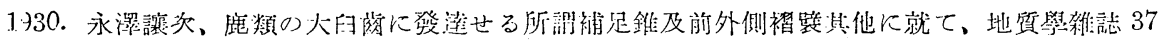

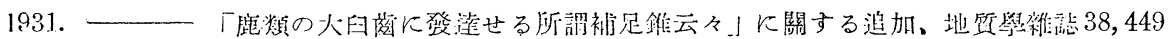

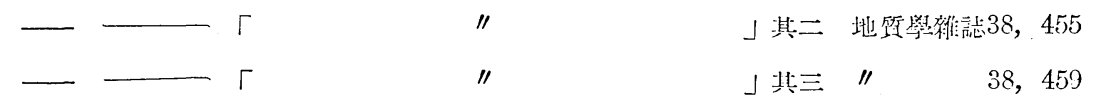

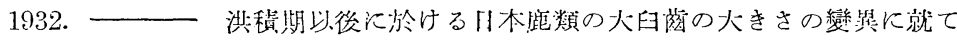
垃啠學猚婄 39,461

植物

1.938. S. Miki, On the change of Japan since the Upper Pliocene and the floral composition at the present. Japanese Journal of Botany.Vol. IX, No. 2.

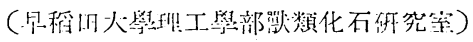

